\title{
Blechnum Orientale Linn - a fern with potential as antioxidant, anticancer and antibacterial agent
}

How Y Lai', Yau Y Lim*1 and Kah H Kim²

\begin{abstract}
Background: Blechnum orientale Linn. (Blechnaceae) is used ethnomedicinally for the treatment of various skin diseases, stomach pain, urinary bladder complaints and sterilization of women. The aim of the study was to evaluate antioxidant, anticancer and antibacterial activity of five solvent fractions obtained from the methanol extract of the leaves of Blechnum orientale Linn.

Methods: Five solvent fractions were obtained from the methanol extract of B. orientale through successive partitioning with petroleum ether, chloroform, ethyl acetate, butanol and water. Total phenolic content was assessed using Folin-Ciocalteu's method. The antioxidant activity was determined by measuring the scavenging activity of DPPH radicals. Cytotoxic activity was tested against four cancer cell lines and a non-malignant cell using MTT assay. Antibacterial activity was assessed using the disc diffusion and broth microdilution assays. Standard phytochemical screening tests for saponins, tannins, terpenoids, flavonoids and alkaloids were also conducted.

Results: The ethyl acetate, butanol and water fractions possessed strong radical scavenging activity $\left(\mathrm{IC}_{50}\right.$ 8.6-13.0 ?g/ $\mathrm{ml})$ and cytotoxic activity towards human colon cancer cell HT-29 $\left(\mathrm{IC}_{50} 27.5-42.8 \mathrm{~g} / \mathrm{ml}\right)$. The three extracts were also effective against all Gram-positive bacteria tested: Bacillus cereus, Micrococcus luteus, methicillin-susceptible Staphylococcus aureus (MSSA), methicillin-resistant Staphylococcus aureus (MRSA) and Stapylococcus epidermidis(minimum inhibitory concentration MIC 15.6-250 ?g/ml; minimum bactericidal concentration MBC 15.6-250 $? \mathrm{~g} / \mathrm{ml}$ ). Phytochemical analysis revealed the presence of flavonoids, terpenoids and tannins. Ethyl acetate and butanol fractions showed highest total phenolic content (675-804 mg gallic acid equivalent/g).

Conclusions: The results indicate that this fern is a potential candidate to be used as an antioxidant agent, for colon cancer therapy and for treatment of MRSA infections and other MSSA/Gram-positive bacterial infectious diseases.
\end{abstract}

\section{Background}

The World Health Organization estimates that $80 \%$ of the world's inhabitants rely mainly on traditional medicines for their health care [1]. Many medicinal plants have proved to successfully aid in various ailments leading to mass screening for their therapeutic components. Today, the search for natural compounds rich in antioxidant, anticancer and antimicrobial properties is escalating due to their medicinal importance in controlling many related chronic disorders such as cancer and cardiovascular diseases. Antioxidants aid in the prevention by scavenging the excess free radicals in the body. Cancer is currently a leading cause of death and growing evidence relates its

* Correspondence: lim.yau.yan@sci.monash.edu.my

1 School of Science, Monash University Sunway Campus, Bandar Sunway, 46150 Petaling Jaya, Selangor, Malaysia

Full list of author information is available at the end of the article occurrence to the oxidative damage to DNA, proteins and lipid in the body [2]. It has been estimated that approximately two-thirds of anticancer drugs approved worldwide up to 1994 were derived from plant sources [3]. The rapid emergence of multiple drug resistant strains of pathogens to current antimicrobial agents has generated an urgent intensive search for new antibiotics from medicinal plants. Many medicinal plants have been screened extensively for their antimicrobial potential worldwide [4-6]. Blechnum orientale Linn. (Blechnaceae) is known as the Centipede fern or 'paku ikan' (by the Malays) or 'Kuan Chung' (by the Chinese). It is natively distributed in Malaysia, in many Asia countries, Australia and Pacific islands. This fern can reach a height of $2.5 \mathrm{~m}$ and commonly grows on exposed low hillsides to $1500 \mathrm{~m}$ altitude mountains. Its leaf is traditionally used as poul- 
tice to treat boils, blisters or abscesses and sores, as a diaphoretic, for stomach pain, urinary bladder complaints and sterilization of women [7-9]. The leaf is also boiled and eaten as vegetable by the natives $[10,11]$.

As part of an ongoing search for natural antibacterial and antioxidant agents from medicinal ferns, we found that the methanol leaf extract of $B$. orientale possessed the strongest potential as broad spectrum bactericidal [12]. Subsequently, we fractionated the methanol extract with increasing polarity of solvents in order to facilitate isolation of bioactive compounds. In this study, we report our findings on the antioxidant, antibacterial and cytotoxic activities of five solvent fractions obtained from the methanol extract of this fern. To the best of our knowledge, this is the first published report on its cytotoxic activity towards human colon cancer cell HT-29 and bactericidal activity towards methicillin-resistant Staphylococcus aureus MRSA.

\section{Methods}

\section{Plant material and extraction}

Blechnum orientale Linn. was obtained from Putrajaya Botanical Garden, Kuala Lumpur. The identity was confirmed by plant taxonomist Anthonysamy S., formerly from University Putra Malaysia and currently a consultant with the landscape consulting firm, Aroma Tropic Limited, Kuala Lumpur. A voucher specimen (LAA007) was deposited at the Herbarium of Monash University Sunway Campus.

Three batches of leaves were collected in April, August and November of 2008. Each batch of the freeze-dried powdered leaves of $B$. orientale (totalling $1.7 \mathrm{~kg}$ from three batches) were repeatedly extracted with methanol $(1: 10, w / v)$ until the extracts were light coloured. The extract was evaporated under reduced pressure to dryness as a dark green mass (total $292 \mathrm{~g}$ ) with $17 \%$ yield. Each batch of the mass was suspended in distilled water $(1: 10, \mathrm{w} / \mathrm{v})$. The suspension was successively partitioned with petroleum ether $40-60^{\circ} \mathrm{C}$, chloroform, ethyl acetate and $n$-butanol. The solvents were evaporated to dryness under reduced pressure. The extracts obtained were eventually freeze-dried to remove any residual water, yielding petroleum ether fraction (PEf), chloroform fraction (Cf,), ethyl acetate fraction (EAf), butanol fraction (Butf) and water fraction (Watf). The yield of each fraction (Table 1) was expressed as a weight percentage of the dry leaves. All the samples were stored at $-70^{\circ} \mathrm{C}$ until used.

\section{Total phenolic content (TPC)}

Total phenolic content (TPC) in extracts was determined using the procedure previously described [12]. Extract solution $(0.3 \mathrm{ml}$, in triplicate) was mixed with $1.5 \mathrm{ml}$ of $10 \%$ Folin-Ciocalteau's reagent and $1.2 \mathrm{ml}$ of $7.5 \%(\mathrm{w} / \mathrm{v})$ sodium carbonate. The mixture was kept in the dark for $30 \mathrm{~min}$ and absorbance was measured at $765 \mathrm{~nm}$. The gallic acid standard curve used was $\mathrm{y}=0.01078 \times\left(\mathrm{R}^{2}=\right.$ $0.9996)$ where $y$ is absorbance at $765 \mathrm{~nm}$ and $\times$ is the concentration of gallic acid in $\mathrm{mg} / \mathrm{l}$. TPC was expressed as mg gallic acid equivalent (GAE)/g extract.

\section{DPPH radical scavenging activity}

The DPPH assay was performed according to the method described by Wang et al. [13]. Ascorbic acid, ?-tocopherol, BHT and Trolox- $\mathrm{C}$ were used as positive controls. Various dilutions of the extract in methanol (100 ? l of 21000 ?g/ml, in triplicate) were added to 100 ?l of DPPH (200 ?M) in a 96-well plate. The mixture was left in the dark for $30 \mathrm{~min}$, before reading the absorbance at $517 \mathrm{~nm}$. The control consisted of methanol instead of the sample. The percentage radical scavenging activity was calculated as follows: scavenging $(\%)=\left(\mathrm{A}_{\text {control }}-\mathrm{A}_{\text {sample }}\right) / \mathrm{A}_{\text {control }} \times$ 100. The result was expressed as $\mathrm{IC}_{50}$, the concentration of the extract to scavenge $50 \%$ of the DPPH radical.

\section{Cytotoxic activity}

The human colonic adenocarcinoma HT-29, human colonic carcinoma HCT-116, human breast adenocarcinoma MCF-7, human leukemia K562 and liver Chang cells were obtained from Monoclonal Lab, Faculty of Medicine, University of Malaya. The cells were cultured in a humidified atmosphere at $37^{\circ} \mathrm{C}$ in $5 \% \mathrm{CO}_{2}$. DMEM supplemented with $10 \%$ fetal calf serum, $1 \%(\mathrm{v} / \mathrm{v})$ penicillin/streptomycin and $2 \mathrm{mM}$ L-glutamine was used as the culture medium of MCF-7, K562 and liver Chang cells. RPMI-1640 supplemented with $10 \%$ fetal calf serum, 2 $\mathrm{mM}$ L-glutamine and $1 \%(\mathrm{v} / \mathrm{v})$ penicillin/streptomycin was used for cell cultures of HT-29 and HCT-116. Cytotoxicity was measured using the MTT (Thiazolyl Blue Tetrazolium Bromide) assay adapted from Tan et al. [14]. Briefly, 96-well plates were seeded with 180 ?l of medium containing an appropriate number of cells (2000 for HCT-116, 3000 for MCF-7, 4000 for Chang liver, 5000 for K562 and 6000 for HT-29). The cells were allowed to adhere for $24 \mathrm{~h}$. Extracts $(20 \mathrm{mg} / \mathrm{ml})$ were dissolved in $20 \%$ DMSO and diluted to $1 \mathrm{mg} / \mathrm{ml}$ with medium. Aliquots of 20 ?L of the extracts at various concentrations (10 - 100 ?g/ml) were added to each well. For the control, 20 ?L of 1\% DMSO in the medium was used instead of extract. The final concentration of DMSO was less than $1 \%$ and as the extracts were used in the dried form, there was no residual butanol or ethyl acetate in the Butf and EAf, respectively. Curcumin (Sigma) was used as positive control. After incubation for $72 \mathrm{~h}, 50$ ?l of $2 \mathrm{mg} / \mathrm{ml} \mathrm{MTT}$ (Sigma) was added to each well. The plate was incubated for another $3 \mathrm{~h}$. The medium of each well was pipetted out and 150 ?1 of DMSO was then added. Absorbance was read at $554 \mathrm{~nm}$ using a Bio-TEK Microplate Scanning 
Table 1: Percentage yield, DPPH radical scavenging activity and total phenolic content of Blechnum orientale extracts

\begin{tabular}{|c|c|c|c|}
\hline Sample & *Yield(g/100 g dry leaves) & **DPPH IC50(?g/ml) & $\begin{array}{l}\text { **Total phenolic content } \\
\text { (mg GAE/g dry weight) }\end{array}$ \\
\hline Crude & $17.2 \pm 1.6$ & $10.9 \pm 1.6^{\mathrm{a}}$ & $346 \pm 48$ \\
\hline PEf & $6.3 \pm 0.6$ & $26.5 \pm 2.2^{b}$ & $154 \pm 10$ \\
\hline $\mathrm{Cf}$ & $0.1 \pm 0.0$ & $37.5 \pm 3.0^{c}$ & $214 \pm 14$ \\
\hline EAf & $1.6 \pm 0.7$ & $8.6 \pm 0.5^{d}$ & $804 \pm 72$ \\
\hline Butf & $2.7 \pm 0.2$ & $10.1 \pm 1.1^{\mathrm{a}}$ & $675 \pm 62$ \\
\hline Watf & $6.5 \pm 0.4$ & $13.0 \pm 1.3^{a}$ & $260 \pm 9$ \\
\hline Ascorbic acid & & $5.3 \pm 0.1^{\mathrm{e}}$ & \\
\hline Trolox-C & & $8.7 \pm 0.1^{d}$ & \\
\hline ?-Tocopherol & & $12.0 \pm 0.7^{a}$ & \\
\hline BHT & & $17.2 \pm 0.2^{f}$ & \\
\hline
\end{tabular}

*Percentage yield is expressed as mean \pm SD from 3 batches of collection.

** Results are mean \pm SD from 3 batches of fern collection and 3 sets of experiments conducted on each batch $(n=9)$.

$\mathrm{Cf}=$ chloroform fraction; $\mathrm{EAf}=$ ethyl acetate fraction; Butf = butanol fraction; Watf = water fraction. Ascorbic acid, trolox-C, ?-tocopherol and BHT (butylated hydroxytoluene) were used as standards.

For each column, values followed by the same letters are not statistically different $(P>0.05)$.

Spectrophotometer. The cytotoxic effect was expressed as $\mathrm{IC}_{50}$, the concentration of extract that reduces cell viability to $50 \%$ of the control.

\section{Antibacterial assays \\ Bacterial strains and media}

Ten strains of bacteria were obtained from stock cultures preserved at $-70^{\circ} \mathrm{C}$ at the Microbiology Lab, School of Science, Monash University Sunway Campus. Five Grampositive bacteria tested were Bacillus cereusATCC14579, Micrococcus luteusATCC4698, methicillin-susceptible Staphylococcus aureus MSSA ATCC25923, methicillinresistant Staphylococcus aureus MRSA ATCC33591 and Stapylococcus epidermidis ATCC12228 and five Gramnegative bacteria tested were Escherichia coliATCC25922, Pseudomonas aeruginosaATCC10145, Klebsiella pneumoniaeATCC10031, Salmonella choleraesuis and Enterobacter aerogenes. All bacteria were grown on nutrient agar (Oxoid).

\section{Disc diffusion test}

Diameter of zone of inhibition was determined using the disc diffusion method as previously described [12]. A swab of the bacteria suspension containing $1 \times 10^{8} \mathrm{CFU} /$ $\mathrm{ml}$ was spread onto petri plates containing Mueller-Hinton agar (MHA). Extracts were dissolved in methanol to final concentration of $10 \mathrm{mg} / \mathrm{ml}$. Sterile filter paper discs ( $6 \mathrm{~mm}$ in diameter) impregnated with $1 \mathrm{mg}$ of plant extracts were placed on the cultured plates. The plates were incubated at $37^{\circ} \mathrm{C}$ for $24 \mathrm{~h}$. Methanol served as negative control while standard streptomycin (10 ?g), oxacillin (1 ?g) and vancomycin (30 ?g) discs were used as positive controls. Antimicrobial activity was indicated by the presence of clear inhibition zones around the discs. The assay was repeated twice and mean of the three experiments was recorded.

\section{Determination of minimum inhibitory concentration (MIC)} and minimum bactericidal concentration (MBC)

Broth microdilution assay was used to determine the MIC and MBC [15]. The crude extract was dissolved in $50 \%$ DMSO at a concentration of $50 \mathrm{mg} / \mathrm{ml}$ which was then diluted with nutrient broth to $1 \mathrm{mg} / \mathrm{ml}$. The ethyl acetate, butanol and water fractions were prepared in nutrient broth. Standard antibiotic vancomycin (Sigma) was prepared at concentrations of $0.48-31.25 ? \mathrm{~g} / \mathrm{ml}$. Test sample (75 ?l) of various concentrations $(2-1000$ ?g/ml) was added into sterile 96-well plates. Bacterial cell suspension (75 ?l) corresponding to $1 \times 10^{6} \mathrm{CFU} / \mathrm{ml}$ was added in all wells except those in columns 11 . Wells of column 11 consisted of $1 \%$ DMSO and broth served as controls to check sterility while those in column 12 were filled with nutrient broth and bacterial suspension to check for adequacy of the broth to support bacteria growth. The plates were covered with sterile sealer and incubated at $37^{\circ} \mathrm{C}$ for $18-24 \mathrm{~h}$. To indicate bacterial growth, 40 ?1 of $0.2 \mathrm{mg} / \mathrm{ml} \mathrm{p-iodonitroterazolium} \mathrm{chlo-}$ ride (INT, Sigma) was added to each well and incubated for another $30 \mathrm{~min}$ [16]. Inhibition of bacterial growth was visible as a clear colourless well and the presence of growth was detected by the presence of pink-red color. The lowest concentration showing no colour change was considered as the MIC. 
For determination of $\mathrm{MBC}$, a loop of liquid from each well that showed no change in colour was streaked onto MHA and incubated at $37^{\circ} \mathrm{C}$ for $24 \mathrm{~h}$. The lowest concentration that showed no growth was taken as the MBC. Experiments were done in triplicate and repeated twice.

\section{Phytochemical screening}

Phytochemical tests for saponins, tannins, terpenoids, flavonoids and alkaloids were performed as previously described [4,17]. Dragendorff reagent was used for alkaloids, foam test for saponins, $\mathrm{Mg}-\mathrm{HCl}$ and $\mathrm{Zn}-\mathrm{HCl}$ for flavonoids, Salkowski test for terpenoids, and ferric chloride and gelatin for tannins.

\section{Statistical analysis}

All data were expressed as mean $\pm \mathrm{SD}$. Statistical analyses were evaluated by one-way ANOVA followed by Tukey HSD test. Values with $\mathrm{P}<0.05$ were considered statistically significant.

\section{Results}

Total phenolic content (TPC) and antioxidant activity Total phenolic content (TPC), based on three batches of fern collection, was determined using the Folin-Ciocalteau reagent and expressed in terms of $\mathrm{mg}$ gallic acid equivalent (GAE)/g extract. The order in decreasing TPC was EAf? Butf (675-804) > > Crude (346) > Watf (260) > Cf (214) > PEf (154) (Table 1).

The antioxidant activity of the methanol crude extract and its various fractions, as measured by the ability to scavenge DPPH free radicals, was compared with those of four standards, namely ascorbic acid, trolox-C, ?-tocopherol and butylated hydroxytoluene (BHT). The lower the $\mathrm{IC}_{50}$, the stronger is the scavenging activity. The scavenging activity in decreasing order was ascorbic acid (5.3 ?g/ml) > EAf ? Trolox-C $(8.7$ ?g/ml $)>$ crude ? Butf ? Watf ? ?-tocopherol $(10.1-13.0$ ?g/ml $)>$ BHT $(17.2$ ?g/ml $)>$ PEf $(26.5 ? \mathrm{~g} / \mathrm{ml})>\mathrm{Cf}(37.5 ? \mathrm{~g} / \mathrm{ml})$. It is clear that EAf was most effective with activity equal to Trolox- $\mathrm{C}$ and greater than ?-tocopherol and BHT, while Butf and Watf were comparable with ?-tocopherol.

\section{Cytotoxic activity}

Table 2 summarizes the cytotoxic activity of the extracts. Due to difficulty in the solubility, the assay was not conducted on PEf and Cf. Considerable cytotoxic activity against the colonic adenocarcinoma cell HT-29 was detected in three fractions: Butf $\left(\mathrm{IC}_{50} 27.5 \mathrm{gg} / \mathrm{ml}\right)>$ Watf $\left(\mathrm{IC}_{50} 33.4\right.$ ?g/ml $)>$ EAf $\left(\mathrm{IC}_{50} 42.8 ? \mathrm{~g} / \mathrm{ml}\right)$, although weaker compared to that shown by curcumin $\left(\mathrm{IC}_{50} 5.4 \mathrm{?g} / \mathrm{ml}\right)$. Butf displayed weak cytotoxicity towards human colonic carcinoma cell HCT-116 ( $\mathrm{IC}_{50} 72.7$ ?g/ml). The fractions were not cytotoxic towards the other cancer cells MCF-7 and $\mathrm{K} 562$ as well as the liver Chang cell $\left(\mathrm{IC}_{50}>100\right.$ ?g/ $\mathrm{ml})$.

\section{Antibacterial activity}

In this study, the susceptibility of five Gram-positive bacteria and five Gram-negative bacteria towards the extracts was tested using the disc diffusion method. No activity was found against all Gram-negative bacteria tested. Table 3 reports the inhibition zone diameter of the crude extract and its fractions against five Gram-positive bacteria. In general, a larger zone is indicative of antibacterial potency. Streptomycin, vancomycin and oxacillin were used as reference antibiotics. Antibacterial activities were found in crude, EAf, Butf and Watf fractions. The bacteria most susceptible was M. luteus (12.8 - $14.3 \mathrm{~mm}$ ). The minimum inhibitory concentration (MIC) and minimum bactericidal concentration (MBC) values are summarized in Table 4. The antibacterial activity against the Gram-positive bacteria except $M$. luteus, in decreasing order was Butf ? Watf (MIC 62.5-125 ?g/ml; MBC 62.5125 ?g/ml) > EAf (MIC 250 ?g/ml; MBC 250-500 ?g/ml). Against $M$. Luteus it is of interest to note that EAf and Butf have lowest $\mathrm{MIC}$ and $\mathrm{MBC}$, indicating relatively strong activity, although these extracts are generally weaker against the other bacteria (MIC and MBC 250500 ?g/ml). Both Butf and Watf have similar minimum inhibition concentration against B. cereus, MSSA and MRSA (MIC 62.5 ?g/ml).

\section{Phytochemical screening}

Phytochemical tests for the ethyl acetate, butanol and water fractions showed absence of alkaloids and saponins. All fractions tested positive for flavonoids, terpenoids and tannins (Table 5).

\section{Discussion}

In recent years, the search for phytochemicals possessing antioxidant, anticancer and antimicrobial activities have been on the rise due to their potential use in the therapy of various chronic and infectious diseases. Epidemiological and experimental studies have implicated oxidative cellular damage arising from an imbalance between free radical generating and scavenging systems as the primary cause of cardiovascular disease, cancer and aging [2]. Due to risk of adverse effects encountered with the use of synthetic antibiotics, medicinal plants may offer an alternative source for antimicrobial agent with significant activity against pathogenic and infective microorganisms. In addition, a number of antibiotics have lost their effectiveness due to the development of resistant strains, mostly through the expression of resistance genes [18]. Results of our studies confirmed the use of $B$. orientale as a traditional medicine. We found strong antioxidant, cytotoxic and antibacterial activities specifically in the 
Table 2: Cytotoxic activities of water, butanol and ethyl acetate fractions of Blechnum orientale

\begin{tabular}{lcccc}
\hline Cell lines & Cytotoxic activity IC 50(?g/ml) & & & Watf \\
& EAf & Butf & & Curcumin \\
\hline HT-29 & $42.8 \pm 6.2$ & $27.5 \pm 1.4$ & $33.4 \pm 1.9$ & $5.4 \pm 0.1$ \\
HCT-116 & $>100$ & $72.7 \pm 4.1$ & $93.9 \pm 3.2$ & $5.5 \pm 0.1$ \\
MCF-7 & $>100$ & $>100$ & $>100$ & n.t. \\
K562 & $>100$ & $>100$ & $>100$ & n.t. \\
Chang & $>100$ & $>100$ & $>100$ & n.t. \\
\hline
\end{tabular}

Results are expressed as mean \pm SD from three sets of experiment, each set in triplicate.

$\mathrm{EAf}=$ ethyl acetate fraction, Butf $=$ butanol fraction, Watf $=$ water fraction

*Curcumin was used as positive control; n.t. denotes not tested.

moderately polar fractions EAf and Butf, as well as the polar fraction Watf. High TPC values found in EAf and Butf (675 - $804 \mathrm{mg}$ GAE/g) imply the role of phenolic compounds in contributing these activities. Plant phenolic compounds have been found to possess potent antioxidant [6,13,19-22], antimicrobial $[4,23,24]$ and anticancer activities [5,25]. Phytochemical analysis revealed presence of flavonoids in the active fractions. This finding corroborates with an early study [26] that reported derivatives of flavones (luteolin, apigenin, acacetin and genkwanin) and flavonols (quercetin, kaempferol, isorhamnetin) in this fern. These flavonoids have been found to possess antioxidant, antitumor and/or antimicrobial properties in various studies [24,25,27-31]. Strong presence of tannins in Watf may explain its potent bioactivities as tannins are known to possess potent antioxi- dant [32], antimicrobial activity [4,33] and anticancer properties [34]. Tannins exert the antimicrobial action by precipitating the microbial protein [33].

Our results on the antioxidant activity showed potential use of this fern as its activities were comparable with the standard antioxidants Trolox-C and ?-tocopherol, while exceeding those for some medicinal plants: Phaulopsis fascisepala has lower scavenging activity compared to ?tocopherol and BHT [19]; the medicinal King fern Angiopteris evecta, $\mathrm{IC}_{50}>90 ? \mathrm{~g} / \mathrm{ml}[20]$; nine selected medicinal plants used in the Indian Traditional System, $\mathrm{IC}_{50} 83-560 ? \mathrm{~g} / \mathrm{ml}[21]$ and six medicinal ferns used in Chinese Traditional System, IC ${ }_{50} 27-400$ ?g/ml [22]. In the evaluation on the anticancer property of this fern, selective cytotoxicity was exhibited against human colon

Table 3: Inhibition zone diameter of Blechnum orientale extracts and standard antibiotics against five Gram-positive bacteriaa $^{a}$

\begin{tabular}{|c|c|c|c|c|c|}
\hline & \multicolumn{5}{|c|}{ bInhibition zone diameter (mm) } \\
\hline & B. cereus & M. Iuteus & MSSA & MRSA & S. epidermidis \\
\hline 'Crude & 9.5 & 11.3 & 9.5 & 10.5 & 9.0 \\
\hline cPEf & 7.0 & 7.5 & 7.9 & 8.0 & - \\
\hline${ }^{c} \mathrm{Cf}$ & 7.5 & 7.8 & - & 8.5 & - \\
\hline cEAf & 11.0 & 13.8 & 10.8 & 13.0 & 9.1 \\
\hline ‘Butf & 11.0 & 14.3 & 12.0 & 13.0 & 11.3 \\
\hline cWatf & 10.3 & 12.8 & 10.5 & 11.5 & 9.8 \\
\hline dStreptomycin & 18.0 & 24.0 & 16.6 & - & - \\
\hline dVancomycin & 18.0 & 30.0 & 17.5 & 20.0 & 19.5 \\
\hline dOxacillin & 8.0 & 48.0 & 22.3 & - & 25.5 \\
\hline
\end{tabular}

Results are mean from three sets of experiments, each set in triplicate.

a No activity was found against Gram-negative bacteria (Escherichia coli, Pseudomonas aeruginosa, Enterobacter aerogenes, Salmonella choleraesius; Klebsiella pneumoniae). Data not shown.

$\mathrm{b}$ Inhibition zone diameter includes diameter of disc (6 $\mathrm{mm})$; (-): not active

c Extracts were tested at $1 \mathrm{mg} /$ disc

d Reference antibiotics discs: Streptomycin 10 ?g; vancomycin 30 ?g; oxacillin 1 ?g 
Table 4: Minimum inhibitory concentration (MIC in ? $\mathrm{g} / \mathrm{ml}$ ) and minimum bactericidal concentration (MBC in ?g/ml) of Blechnum orientale extracts

\begin{tabular}{|c|c|c|c|c|c|}
\hline & B. cereus & M. Iuteus & MSSA & MRSA & S. epidermidis \\
\hline & \multicolumn{5}{|c|}{ Minimum Inhibitory concentration (MIC, ?g/ml) } \\
\hline Crude & 125 & 62.5 & 125 & 125 & 125 \\
\hline EAf & 250 & 15.6 & 250 & 250 & 250 \\
\hline Butf & 62.5 & 15.6 & 62.5 & 62.5 & 125 \\
\hline Watf & 62.5 & 31.3 & 62.5 & 62.5 & 62.5 \\
\hline \multirow[t]{2}{*}{ Vancomycin } & 1.9 & 0.5 & 1.9 & 1.9 & 1.9 \\
\hline & \multicolumn{5}{|c|}{ Minimum bactericidal concentration (MBC, ?g/ml) } \\
\hline Crude & 125 & 62.5 & 250 & 125 & 125 \\
\hline EAf & 250 & 15.6 & 500 & 500 & 500 \\
\hline Butf & 62.5 & 62.5 & 125 & 125 & 125 \\
\hline Watf & 62.5 & 62.5 & 125 & 62.5 & 125 \\
\hline Vancomycin & 1.9 & 0.5 & 1.9 & 1.9 & 1.9 \\
\hline
\end{tabular}

Results are mean from three sets of experiments, each set in triplicate.

cancer cells HT-29 and HCT-116, while no effect was detected against MCF-7, K562 and liver Chang cells. Due to the selectivity towards colon cancer cells, we chose curcumin as a positive control as it is currently widely used in clinical trials for chemoprevention of colon cancer $[35,36]$. Amongst the fractions, the butanol fraction displayed the most potential $\left(\mathrm{IC}_{50} 27.5 \mathrm{gg} / \mathrm{ml}\right)$ although weaker than curcumin $\left(\mathrm{IC}_{50} 5.4 \mathrm{gg} / \mathrm{ml}\right)$. The impure nature of the Butf may have reduced the effect of the potential anticancer component present in that fraction which if isolated, may then improve its $\mathrm{IC}_{50}$. Nevertheless, the $\mathrm{IC}_{50}$ value of Butf satisfies the criteria established by the American National Cancer Institute (NCI) of cytotoxicity activity, which is an $\mathrm{IC}_{50}<30$ ?g/ml in the preliminary assay for crude extracts [37]. Our result on the noncytotoxicity towards MCF-7 ( $\mathrm{IC}_{50}>100$ ?g/ml) corroborates that reported previously on this fern [38]. It is known that the use of chemotherapeutic drugs in cancer may cause detrimental effects to normal cells, hence there is a need in the search for drugs which selectively act on tumor cells. Non-malignant Chang cells have been used in cytotoxicity studies to test the effects of drugs/ agents on normal cells. For example, two chemotherapeutic compounds against HepG2 cells, eurycomanone and tamoxifen, are reported to be cytotoxic towards Chang cells [39]. Curcumin has also been reported to induce cell death in normal cells such as rat thymocytes and human $\mathrm{T}$ cells [40]. Therefore, the selective cytotoxicity shown by the fractions towards HT-29 and noncytotoxicity toward the liver Chang cells indicates a promising potential for Butf to be developed for use in colon cancer therapy.

Our results on the antibacterial activity confirmed the traditional use of $B$. orientale in the treatment of skin diseases, urinary bladder and stomach discomforts. Its bactericidal activity against B. cereus, M. luteus, MSSA, MRSA and S. epidermidis showed potential use of this

Table 5: Phytochemical analysis of Blechnum orientale active fractions

\begin{tabular}{lccc}
\hline Plant constituent & EAf & Butf \\
\hline Alkaloids & - & - & Watf \\
Saponins & - & - & - \\
Flavonoids & ++ & ++ \\
Terpenoids & + & ++ \\
Tannins & + & ++
\end{tabular}

+++ Strong; ++ medium; + poor presence; - absent; classification was based on observation of colour intensity and amount of precipitate 
fern for the treatment of infectious diseases caused by these bacteria, which have been reported to be skin and food-borne pathogens in various diseases [41-44]. MRSA, probably the most challenging pathogen affecting patients worldwide, is resistant to ?-lactams antibiotics used in the treatment of staphylococcal infections [45]. When compared with earlier reports on the antibacterial activity of this fern, we found a few similarities as well as discrepancies. While we found strong activity against $M$ luteus, Nick et al. [9] reported no activity. The inactivity against K pneumonia, E. coli, P. aeruginosa was also reported by Banerjee and Sen [46] but in contrast with that reported by Maridass and Ghantikumar [8]. The bactericidal activity of this fern against $S$ aureus has also been reported by Maridass and Ghantikumar [8]. The discrepancies in the results could be due to a few factors such as different extracts and methods used, parts of the plant examined, variation in ecological factors, genetic changes, state of maturity and the strains of test microorganisms [47].

The inactivity against all Gram-negative bacteria tested could be due to the impermeable nature of the outer membrane of the bacteria [48]. When compared with some medicinal plants such as Curcuma longa L. (MIC 1000-6400 ?g/ml) [49] and Quercus infectoria(MIC 130 $1000 ? \mathrm{~g} / \mathrm{ml}$ ) [50], our result on anti-MRSA potency of this fern (MIC 62.5 ?g/ml; MBC 62.5-125 ?g/ml in Butf and Watf) is very promising. Nevertheless, its activity is weak compared to the reference, vancomycin (MIC 1.9 ?g/ml). It should be noted that the impure nature of the active fractions may have diluted its efficacy as compared to a pure antibiotic compound. Stronger antibacterial activity against $B$. cereus and $S$. aureus (MIC 62.5 ?g/mL) were found in the Butf and Watf fractions compared to those reported in Grewia occidentalis, Polystichum pungens, Cheilanthes viridis and Malva parvifolia (MIC 500-5000 ?g/ml) [51], Anethum graveolens, Foeniculum vulgare and Trachyspermum ammi (MIC 20-80 mg/ml) [4] while its activity was comparable to some selected Yemeni medicinal plants $\mathrm{MIC}<250$ ?g/ml [5]. Our result concerning the strongest antibacterial activity in the water fraction corroborates those of Dahot [52] who showed that the aqueous extracts of the plant leaves investigated showed significant antimicrobial activity, compared to the other organic counterparts.

\section{Conclusions}

Strong antioxidant, antibacterial and anticancer properties were confirmed in the ethyl acetate, butanol and water fractions. These activities may be due to the strong occurrence of polyphenolic compounds such as flavonoids and tannins. The antioxidant scavenging activity was comparable to those of Trolox-C and ?-tocopherol. Selective cytotoxic activity was detected against colon cancer cells HT-29 while noncytotoxic effect to liver Chang cells was established. The water and butanol fractions showed significantly strong bactericidal activity against all Gram-positive bacteria tested, with special reference to MRSA. These findings provide scientific evidence to support its traditional medicinal uses and indicate a promising potential for the development of an antioxidant, anticancer and antibacterial agent from this plant.

\section{Competing interests \\ The authors declare that they have no competing interests.}

\section{Authors' contributions}

HYL carried out the experimentation as part of PhD study and drafted the manuscript. YYL supervised the work, evaluated the data and corrected the manuscript for publication. KHK supervised the work and evaluated the data on the cytotoxicity study. All authors read and approved the final manuscript.

\section{Acknowledgements}

This study was supported by a research grant from Monash University Sunway Campus. We are grateful to Professor Cheah SH from the Physiology Department, University of Malaya for the panel of cell lines, Dr Stacey Yong for the helpful discussions in the antibacterial work and the administrators of Putrajaya Botanical Garden, Kuala Lumpur for the supply of the fern.

\section{Author Details}

'School of Science, Monash University Sunway Campus, Bandar Sunway, 46150 Petaling Jaya, Selangor, Malaysia and 2Department of Physiology, Faculty of Medicine, University of Malaya, 50603 Kuala Lumpur, Malaysia

Received: 25 January 2010 Accepted: 30 April 2010

Published: 30 April 2010

\section{References}

1. Gurib-Fakim A: Medicinal plants: Traditions of yesterday and drugs of tomorrow. Mol Aspects Med 2006, 27:1-93.

2. Halliwell B: Antioxidants in human health and disease. Annu Rev Nutr 1996, 6:33-50

3. Vickers A: Botanical medicines for the treatment of cancer: Rationale, overview of current data, and methodological considerations for Phase I and II trials. Cancer Invest 2002, 20:1069-1079.

4. Kaur GJ, Arora DS: Antibacterial and phytochemical screening of Anethum graveolens, Foeniculum vulgare and Trachyspermum ammi. BMC Complement Altern Med 2009, 9:30.

5. Mothana RA, Lindequist U, Gruenert R, Bednarski PJ: Studies of the in vitro anticancer, antimicrobial and antioxidant potentials of selected Yemeni medicinal plants from the island Soqotra. BMC Complement Altern Med 2009, 9:7.

6. Adedapo AA, Jimoh FO, Koduru S, Masika PJ, Afolayan AJ: Assessment of the medicinal potentials of the methanol extracts of the leaves and stems of Buddleja saligna. BMC Complement Altern Med 2009, 9:21.

7. Ahmad F, Holdsworth DK: Medicinal plants of Sabah, East Malaysia Part I. Pharm Biol 2003, 41:340-346.

8. Maridass M, Ghantikumar S: Antibacterial activity of leaves of Blechnum Orientale L. Pharmacologyonline Newslett 2008, 3:58-60.

9. Nick A, Rali T, Sticher O: Biological screening of traditional medicinal plants from Papua New Guinea. J Ethnopharmacol 1995, 49:147-156.

10. Piggott AG: Ferns of Malaysia in colour. Tropical Press, Kuala Lumpur; 1996:400-401.

11. Sharief MU, Rao RR: Ethnobotanical studies of Shompens - A critically endangered and degenerating ethnic community in Great Nicobar Island. Curr Sci 2007, 93:1623-1628.

12. Lai HY, Lim YY, Tan SP: Antioxidative, tyrosinase inhibiting and antibacterial activities of leaf extracts from medicinal ferns. Biosci Biotechnol Biochem 2009, 73:1362-1366. 
13. Wang KJ, Yang CR, Zhang YJ: Phenolic antioxidants from Chinese toon (fresh young leaves and shoots of Toona sinensis. Food Chem 2007, 101:365-371.

14. Tan GK, Kim KH, Cheah SH: Morphological and biochemical changes of Andrographolide-induced cell death in human prostatic adenocarcinoma PC-3 cells. In vivo 2005, 19:551-557.

15. Andrews JM: Determination of minimum inhibitory concentrations. $J$ Antimicrob Chemoth 2001, 48(S1):5-16.

16. Eloff JN: A sensitive and quick microplate method to determine the minimal inhibitory concentration of plant extracts for bacteria. Planta Medica 1998, 64:711-713.

17. Silva GL, Lee IS, Kinghorn AD: Special problems with the extraction of plants. In In Natural Products Isolation Edited by: Cannell RJP. Totowa, New Jersey: Humana Press Inc; 1998:356-357.

18. Berahou AA, Auhmani A, Fdil N, Benharref A, Jana M, Gadhi CA: Antibacterial activity of Quercus ilex bark's extracts. J. Ethnopharmaco 2007, 112:426-429.

19. Adesegun SA, Fajana A, Orabueze $\mathrm{Cl}$, Coker HAB: Evaluation of antioxidant properties of Phaulopsis fascisepala C.B.Cl. (Acanthaceae). Evid Based Complement Altern Med 2009, 6:227-231.

20. Hutadilok-Towatana N, Chaiyamutti P, Panthong K, Mahabusarakam W, Rukachaisirikul V: Antioxidant and free radical scavenging activities of some plants used in Thai Folk Medicine. Pharm Biol 2006, 44:221-228.

21. Gache RN, Dhole NA: Antioxidant and possible anti-Inflammatory potential of selected medicinal plants prescribed in the Indian Traditional System of medicine. Pharm Biol 2006, 44:389-395

22. Chang HC, Huang GH, Agrawal DC, Kuo CL: Antioxidant activities and polyphenol contents of six folk medicinal ferns used as "Gusuibu". Bot Studies 2007, 48:397-406.

23. Alcaraz LE, Blanco SE, Puig ON, Tomas F, Ferretti FH: Antibacterial activity of flavonoids against methicillin-resistant Staphylococcus aureus strains. J Theor Biol 2000, 205:231-240.

24. Cushnie TPT, Lamb AJ: Antimicrobial activity of flavonoids. Int J Antimicrob Agents 2005, 26:343-356.

25. Lin $Y$, Shi R, Wang $X$, Shen HM: Luteolin, a flavonoid with potential for cancer prevention and therapy. Curr Cancer Drug Targets 2008, 8:634-46.

26. Yusuf UK: Flavonoid Glycosides in the Fern Blechnum orientale Linn. Am FJ 1994, 84:69-70

27. Lopez-Lazaro M: Distribution and biological activities of the flavonoid luteolin. Mini Rev Med Chem 2009, 9:31-59.

28. Yoshida T, Konishi M, Horinaka M, Yasuda T, Goda AE, Taniguchi H, et al.: Kaempferol sensitizes colon cancer cells to TRAIL-induced apoptosis. Biochem \& Biophys Res Comm 2008, 375:129-133.

29. Zielinska M, Kostrzewa A, Ignatowicz E, Budzianowski J: The flavonoids, quercetin and isorhamnetin 3-O-acylgucosides diminish neutrophil oxidative metabolism and lipid peroxidation. Acta Biochim Pol 2001 48:183-189.

30. Yokozawa T, Dong E, Liu ZW, Shimizu M: Antioxidative activity of flavones and flavonols in vitro. Phytother Res 1997, 11:446-449.

31. Kale A, Gawande S, Kotwal S: Cancer phytotherapeutics: Role for flavonoids at the cellular level. Phytother Res 2008, 2:567-577.

32. Zhang LL, Lin YM: Tannins from Canarium album with potent antioxidant activity. J Zhejiang Univ Sci B 2008, 9:407-415.

33. Scalbert A: Antimicrobial properties of tannins. Phytochem 1991 30:3875-3883.

34. Kandil FE, Nassar MI: A Tannin anti-cancer promoter from Terminalia Arjuna. Phytochem 1998, 47:1567-1568.

35. Cen L, Hutzen B, Ball S, DeAngelis S, Chen CL, Fuchs JR, Li CL, Li PK, Lin JY: New structural analogues of curcumin exhibit potent growth suppressive activity in human colorectal carcinoma cells. BMC Cancer 2009, 9:99.

36. Johnson JJ, Mukhtar H: Curcumin for chemoprevention of colon cancer. Cancer Lett 2007, 255:170-81.

37. Suffness M, Pezzuto JM: Assays related to cancer drug discovery. In In Methods in Plant Biochemistry. Assays for Bioactivity Edited by: Hostettmann K. London: Academic Press; 1990:71-133.

38. Nor Aini AS, Merrina A, Stanslas J, Sreeramanan S: Cytotoxic potential on breast cancer cells using selected forest species found in Malaysia. Int J of Cancer Res 2008, 4:103-109.

39. Zakaria Y, Rahmat A, Pihie AHL, Abdullah NR, Houghton PJ: Eurycomanone induce apoptosis in HepG2 cells via up-regulation of p53. Cancer Cell Int 2009, 9:16
40. Salvioli S, Sikora E, Cooper EL, Franceschi C: Curcumin in cell death processes: A challenge for CAM of age-related pathologies. Evid Based Complement Altern Med 2007, 4:181-190.

41. Chiller K, Selkin BA, Murawawa GJ: Skin microflora and bacterial infections of the skin. J Invest Derm Symp P 2001, 6:170-174.

42. Fluit AC, Schmitz FJ, Verhoef J, the European SENTRY Participant Group: Frequency of isolation of pathogens from bloodstream, nosocomial pneumonia, skin and soft tissue, and urinary tract infections occurring in European patients. Eur J Clin Microbiol 2001, 20:188-191.

43. Schoeni JL, Wong AC: Bacillus cereus food poisoning and its toxins. J Food Prot 2005, 68:636-648.

44. Rasheed MU, Awole M: Staphylococcus epidermidis: A commensal emerging as a pathogen with increasing clinical significance especially in nosocomial infections. The Internet J Microbiol 2007, 3:2.

45. Sadaka SM, El-Ghazzawy EF, Harfoush RA, Meheissen MA: Evaluation of different methods for the rapid diagnosis of methicillin-resistance in Staphylococcus aureus. Afr J Microbiol Res 2009, 3:49-55.

46. Banerjee RD, Sen SP: Antibiotic activity of Pteridophytes. Econ Bot 1980 34:284-298.

47. Zaidi SFH, Yamada K, Kadowaki M, Usmanghani K, Sugiyama T: Bactericidal activity of medicinal plants, employed for the treatment of gastrointestinal ailments, against Helicobacter pylori. JEthnopharmacol 2009, 121:286-291.

48. Russell AD: Similarities and differences in the responses of microorganisms to biocides. J Antimicrob Chemoth 2003, 52:750-763.

49. Kim KJ, Yu HH, Cha JD, Seo SJ, Choi NY, You YO: Antibacterial activity of Curcuma longa L. against methicillin-resistant Staphylococcus aureus. Phytotherapy Res 2005, 19:599-604

50. Chusri S, Voravuthikunchai SP: Quercus infectoria: A candidate for the control of methicillin-resistant Staphylococcus aureus infections. Phytotherapy Res 2008, 22:560-562

51. Grierson DS, Afolayan AJ: Antibacterial activity of some indigenous plants used for the treatment of wounds in the Eastern Cape, South Africa. J Ethnopharmacol 1999, 66:103-106.

52. Dahot MU: Antibacterial and antifungal activity of small protein of Indifogera oblongifolia leaves. JEthnopharmacol 1999, 64:277-282.

\section{Pre-publication history}

The pre-publication history for this paper can be accessed here: http://www.biomedcentral.com/1472-6882/10/15/prepub

doi: $10.1186 / 1472-6882-10-15$

Cite this article as: Lai et al., Blechnum Orientale Linn - a fern with potential as antioxidant, anticancer and antibacterial agent BMC Complementary and Alternative Medicine 2010, 10:15

\section{Submit your next manuscript to BioMed Central and take full advantage of:}

- Convenient online submission

- Thorough peer review

- No space constraints or color figure charges

- Immediate publication on acceptance

- Inclusion in PubMed, CAS, Scopus and Google Scholar

- Research which is freely available for redistribution 